\title{
PROJECT SILVER COLUMBIA AND LONGSTAY: INSIGHTS FROM JAPAN FOR THE STUDY OF THE WORLDWIDE ELDERLY MIGRATION ${ }^{123}$
}

\section{Marcelo Daisuke Yamaki ${ }^{4}$ Maria Coleta Ferreira Albino de Oliveira ${ }^{5}$}

\begin{abstract}
Resumo: Como nas economias mais desenvolvidas do mundo, as baixas taxas de fecundidade japonesas têm sido uma questão premente nas últimas décadas. Nesse sentido, o debate sobre migração é crucial não apenas para manter os benefícios alcançados pelos japoneses durante o período de alto crescimento econômico no final do século 20, mas também para prosperar nos próximos anos. A maioria das políticas de migração convida jovens a imigrar, no entanto, no Japão, houve uma iniciativa pública no final dos anos 80 , que promoveu a emigração de idosos, o projeto Silver Columbia. Este artigo apresenta uma revisão de Silver Columbia e suas consequências usando artigos de revistas acadêmicas e da mídia discutindo argumentos contra e a favor de sua implementação. A experiência foi uma medida controversa para apoiar uma política populacional nacional e fracassou devido à falta de aplicação dos princípios básicos de marketing no setor público. O estudo de caso traz informações valiosas para a migração mundial de idosos, a sua participação ativa nas sociedades de destino e o turismo.
\end{abstract}

Palavras-chave: Japão. Demografia. Envelhecimento. Migração. Política social.

1 This study was financed in part by the Coordenação de Aperfeiçoamento de Pessoal de Nível Superior - Brasil (CAPES) - Finance Code 001.

2 Article received and accepted in 2019.

3 This paper was presented at the XII International Congress on Japanese Studies in Brazil (CIEJB) / XXV National Meeting of University Teachers of Language, Literature and Japanese Culture (ENPULLCJ) held at the State University of Campinas - São Paulo, Brazil, between August 28th and 30th, 2018

4 Faculty at Federal Educacional; $\mathrm{PhD}$ from Universidade Estadual de Campinas, Campinas, Brazil; marcelo.yamaki@gmail.com; (ORCID iD: https://orcid.org/0000-0003-2899-7853).

5 Professora Associada II da Universidade Estadual de Campinas (Departamento de Demografia/IFCH) e pesquisadora do Núcleo de Estudos de População "Elza Berquó" (NEPO/UNICAMP). Não possui ORCID. Lattes: http://lattes.cnpq.br/3454564839423365 


\begin{abstract}
As in most developed economies of the world, Japanese low fertility rates have been a pressing issue for the last decades. In this sense, the debate on migration is crucial not only to keep the benefits attained by the Japanese during the period of high economic growth in the end of 20th century, but also to thrive in the years to come. Most migration policies related to the balance of age cohorts invites younger people to immigrate; however, in Japan, there was a public initiative in the end of the 1980's, which promoted the emigration of elderly, the Silver Columbia project. This paper presents a review of Silver Columbia and its aftermath using articles from academic journals and media discussing arguments against and for its implementation. The experience was both a controversial measure to support a nationwide population policy and failed because of the lack of application of basic marketing principles in the public sector. The case study brings valuable insight for the worldwide elderly migration, their active participation in host societies and tourism.
\end{abstract}

Keywords: Japan. Demography. Aging. Migration. Social Policy.

\title{
1. Introduction
}

Coulmas (2007) draws attention to the fact that the popularization of technical terms from the field of Demography is an evidence that the Japanese people are aware of their severe demographic context. Initially, Japan was called an Ageing Society, 高齢化社会 ${ }^{6}$; later, Aged Society, 高齢社会 ${ }^{7}$; then, came the superlatives Hyperageing Society, 超高齢化社会 ${ }^{8}$, and Hyper-Aged Society, 超高齢社会 9 (KOCH, HERMER, COULMAS; 2007). The term related to ageing is often combined with the term regarding fertility - the number of children per mother - as 少子高齢社会 ${ }^{10}$, as consequence of the fact that both phenomena are related to each other. The drop in the number of children together with a high life expectancy leads to an increase in the average age of the population as a whole, a process known as social ageing. All formal definitions are linked to the high proportion of people above 65 years of age in the Japanese population. The Figure 1 shows the fast increase in the proportion of elderly in parallel to a decrease in the proportion of children.

6 Kôreika shakai.

7 Kôreika shakai.

8 Chôkôreika shakai.

9 Chôkôreika shakai.

10 Shôshi kôrei shakai. 
Figure 1 - Proportion of population below 15 and 65 or above - Japan $-1920-2015$

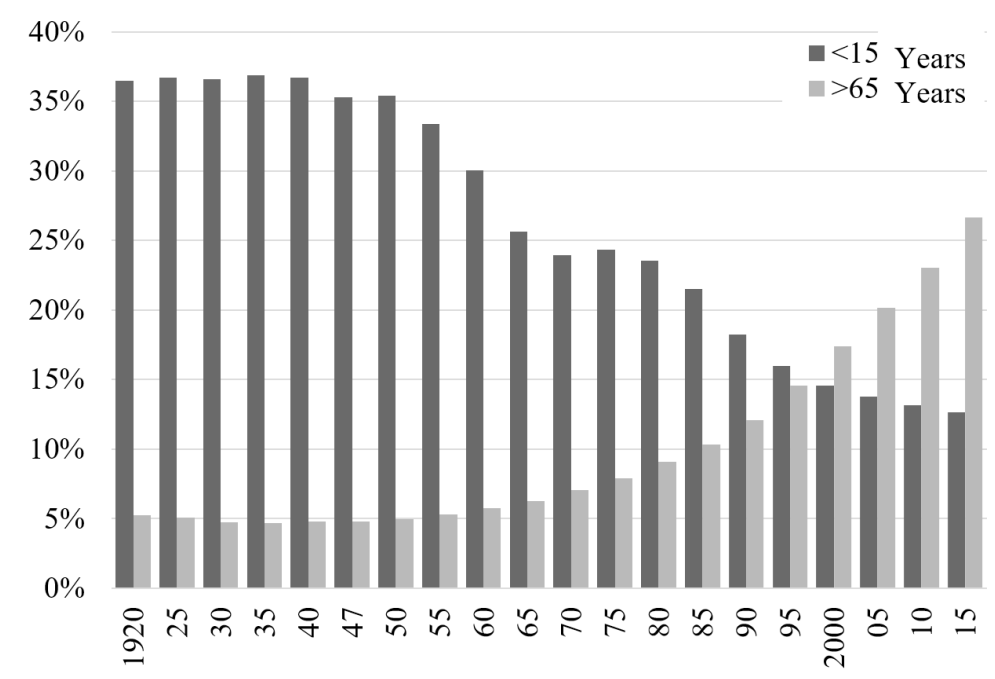

Source: Ministry of Internal Affairs and Communications. Japanese population Censuses from 1920 to 2015 . Elaborated by me.

The phenomenon of social ageing implies a smaller workforce. That brings pressure for changes in the participation of women in Japanese society. It is not only the feminist's political influence or the movements for more egalitarian societies that increase women participation in the formal labor market, but also the demography of low fertility rates and smaller families. The discussion is decades old, however, important enough to be reminded. The role of women as the sole responsible for household activities - including caregiving of children and elderly - became unsustainable in contemporary Japanese society since it is combined with the burden of women's engagement in financial provision (MARTIN, 1989). Life expectancy and health conditions of the people advanced in age are improving through progress in educational levels, medicine and technology, but a considerable part of this age group is or will be dependent on intensive caregiving, which the limited Japanese welfare system is still unable to provide (GOODMAN, HARPER; 2007).

Matsutani (2006) considers that the core of the Japanese demographic crisis is in accepting the unavoidable population decrease and the contraction of the economy, leading to meaningless efforts in promoting parenthood and inviting immigrant workers. Even if it was possible to instantaneously increase the fertility to high levels, it would take years until these newborns could actively participate as citizens in the Japanese society and contribute to the economic growth. The other alternative, also results in the problem of ageing. Regardless their nationality, 
people age. In the moment that foreigners acquire the same rights as the overall population, they will become target of concerns by people in charge of the healthcare and pension systems.

Among the many public policies aiming to mitigate the social ageing impact on the Japanese society, there was one in particular which became famous for its lack of popularity at the time of implementation. The name of the project was Silver Columbia Plan (SCP), officially known in Japan as「シルバーコロンビア計画“92”－豊 かな第二の人生を海外で過ごすための海外居住支援事業」 ${ }^{11}$. Most migration policies dealing with the balance of age cohorts invites younger people to immigrate, however, this public initiative from the end of the 1980's promoted the emigration of the elderly. Later the government abandoned the idea, but a private for-profit foundation called LongStay Foundation, inspired by SCP, created a program of elderly tourism. This text presents a review of Silver Columbia and its aftermath using articles from academic journals and media discussing arguments against and for its implementation. The experience was a controversial measure to support a nationwide population policy and failed because of the lack of application of basic marketing principles in the public sector. As a case study, the experience can bring valuable insight for the worldwide elderly migration, their active participation in host societies and tourism.

The name of the project was an homage to the 500 years since the arrival of Christopher Columbus to the Americas, date celebrated in 1992, when the project would be in full operation (SCHREIBER, 2013). The program was announced as a mean for the retired population to experience living abroad. Its requirement was an amount of savings or an income level (pension) high enough to live in the destination country without an occupation, because the bilateral agreements between Japan and these host countries did not include the provision of working visas. Building complexes called "Silver Towns", similar to small cities, was part of the plan; these would have a population of around 1,000 inhabitants of elderly residents and the necessary infrastructure to provide an appropriate standard of living, including Japanese doctors (YATES, 1986). Many criticized the Ministry of International Trade and Industry (MITI), which developed the program and the program was received with suspicion, even considered analogous to the mythical practice of 姥捨 ${ }^{12}$, the abandoning of an elderly to die. The project was also described as "dumping" - exports of a product at a price that is lower in the foreign market than it is in the domestic market (SWINBANKS, 1986). Carone (1989) considers beneficial the offering of tourism products in Italy for people at advanced ages, but makes clear that these products should not be by any means associated with the SCP.

11 [Shirubâ Koronbia keikaku "92" - Yutakana daini no jinsei wo kaigai de sugosu tame no kaigai kyojû shien jigyô] or "Silver Columbia Plan '92' - Overseas living support project to spend a wealthy second life overseas" (Translated by me).

12 The practice of 姥捨て [obasute or ubasute] is portrayed in several movies inspired by the popular Japanese novel楢山節考 [Narayamabushi Kô] by深沢七郎 [Fukazawa Shichirô] published in 1956 (ANDERSON, RICHIE; 1960). 


\section{Findings and arguments}

According to the Nihon Keizai Shinbun (日本経済新聞, 2008), the politician Takao Kitabata is credited as the creator of the SCP. Kitabata stated that would live in Spain upon retirement instead of following the common path of 天下り ${ }^{13}$. He withdraw from public service in 2008, but the high cost of living caused by years of inflation and the exchange rate between the Japanese yen and the euro turned impossible his plan of living in Spain from pension earnings. More than thirty years ago, when the SCP was under study, Kitabata estimated that acquisition of a $200 \mathrm{~m}^{2}$ property in Spain would revolve around 7-11 million yen and monthly cost of living around 100-150 thousand yen per person. "A 退職金 ${ }^{14}$ of 20 million yen and a monthly pension of 200 thousand yen are more than enough for a couple to live abroad comfortably", he said ${ }^{15}$. The recent movements towards a strong yen ${ }^{16}$ were extremely favorable for Japanese spending abroad; the Japanese economy was still growing following the trend from the 1970's; and, the participation in the SCP was subject to a reasonable income level. In summary, it was unlikely that the retirees overseas would face financial hardship in the near future. From the point of view of the host societies, an influx of Japanese capital, local investments to receive the Japanese and an increase in the number of tourists and family members of the retirees were some of the expected benefits (RIES, 1986).

A possible criticism to the SCP is a supposed disregard towards sociocultural differences between the Japanese and host societies, leading pensioners into unnecessary situations of stress or conflict. The newspaper El País presented Kitabata claims that the conception of the SCP started when he witnessed groups of German and Dutch senior citizens in Spain, during his assignment as a Commercial attaché at the Japanese Embassy in Madrid (RIES, 1986). He assumed that, in a similar way, the Japanese pensioners should have no problems adapting to foreign cultures. The politician was an officer of the Ministry of International Trade and Industry (MITI), an institution that calculated there were 480 thousand Japanese living abroad, half of them for long-term business activities in 1986, the year in which the prospection of sites for the Silver Towns started. Indeed, Japan and the Japanese are integrated to the global economy in such a way that living experiences abroad at any age should not sound disparate. As

13 Many Japanese politicians are hired in the private sector as high-ranked managers of large companies after their retirement from the public sector; this is known as 天下り [amakudari] (MITSUBISHI CORPORATION, 1983). The practice raises ethical concerns as often times can be traced back to traffic of influence in favor of these companies during their mandates.

14 Depending on their career, Japanese people are entitled to receive a lump sum upon retirement followed by a monthly pension for life. The lump sum is known as 退職金 [taishokukin].

15 According to Kitabata himself, the average 退職金 [taishokukin] in 1986 was 21 million yen and the average monthly pension was of 184 thousand yen in 1986 (RIES, 1986).

16 The exchange rate shifted from 240 yen per U.S. dollar in August 1985 to 150 yen in the mid-1986, following an internationally coordinated effort to increase domestic consumption and regulate the international trade balance (JINUSHI, KUROKI, MIYAO; 2000). 
an example, U.S. citizens in 1987 had their own informal retirement communities in the Caribbean Islands, Spain and other foreign countries (LADE, 1987). Furthermore, there are studies about migration of the same age cohort from Russia to Germany; from Turkey and Morocco to Europe; from Japan to Southeast Asia; from Singapore to Australia; and, from Europe to southern Europe (TOYOTA, BÖCKER, GUILD; 2006).

The problem was not with the service itself, as the SCP led to the creation of LongStay Foundation, a private for-profit organization, which provided a similar product after the government abandoned it (SCHREIBER, 2013; YAMADA, 2013). In practice, expectations towards the function of the public sector molded the negative opinions and raised unfair suspicions. Direct involvement of the public sector presupposes the definition of the operating principles of the society, the performance of public services critical to public interest and the provision of services that the private and non-profit sectors cannot or are not interested in dealing with (KOTLER, 2007, p. 6). The SCP was seen as a drastic and urgent policy oriented towards the solution of a severe social issue, but as a commercial service from LongStay Foundation, the prospect of providing international trips for a specific market characterized by age cohort can be regarded as simple and viable. Another indication that the distinction between public and private governance mattered is that although the discussions about the SCP considered the possibility of permanent migration, the voluntary character of the plan was never discarded. It was not a fascist State program of exile - aiming to force people to permanently be removed from their own country -, but open to the possibility of participants return to Japan whenever they desired so. The real wealth in advanced democracies with developed economies such as Japan is being able to offer to its citizens a diversity of lifestyles and SCP was in line with this thought.

A newspaper article enumerates an extensive list given by MITI with the desirable conditions of a country to receive a proposal to host SCP (EFE, 1986). The list is long, but fair. It included excellent natural resources; comfortable climate; and, availability of golf courses, tennis courts and places for other sports. It continues with availability of cultural activities; possibility of short local trips; low housing cost; ease to contact and low opposition to SCP from local population; supply of imported Japanese food and ingredients; and, proper medical facilities. Topics related to the government were not excluded: good country relationships with Japan and political stability and favorable exchange rate in the long-term; and, bilateral agreements in order to avoid double taxation (by Japanese and local government). All these, of course, were searched for in Spain - where Kitabata had the preliminary ideas - and through several countries in the world. The broad prospection for the conditions demonstrates an effort to reduce tangible and intangible personal costs for the Japanese retirees.

There was no lack of interested elders in Japan (EFE, 1987). According to Pablo Muller, representative of the Spanish Tourism Office in Tokyo: 
"Las llamadas telefônicas inundaron la oficina española de turismo en Tokyo, que se ha visto obligada a organizar dos reuniones a la semana para explicar cómo es el país y responder a las minuciosas preguntas de los nuevos emigrantes. A estas reuniones han assistido ya quinhentas personas y la lista de espera sobrepasa el millar" (EFE, 1987, p. 33) $)^{17}$

Muller oriented the grey-haired Japanese to do not worry about the increase in housing prices due to the high demand, to try to integrate with locals and make efforts to know Spain before making any long-term plans. Japanese tourism agencies organized short trips of four or five days and longer ones of 25 days. Around 70 people chose the first option and almost a hundred, the second one. The larger group stayed in the Spanish Costa del Sol region, which few years later became the place of birth of an active Japanese club named "Costa Amigos" (伊 藤, 2012).

The investments for the SCP were expected to come primarily from the private sector and the urban planning was particularly stressed in the bilateral negotiations between the MITI and the host countries (EFE, 1986). From the start, the project was not expected to be subsidized by taxpayers. That could be another source of criticism, as in such situation, the life of retired people in international resorts would be financed by younger Japanese workers. Regarding the urban planning, one option under consideration was Japanese-only communities and the other, mixed areas with Japanese and people of other nationalities in the same building. In Mijas, a town in the Costa del Sol, a company called "Mijas International Resort" invested a billion Spanish pesetas to purchase 800 thousand $\mathrm{m}^{2}$ of land to build 516 houses for the Japanese expected to come; the project even included a Japanese garden of 35 thousand $\mathrm{m}^{2}$ (GARCIA, 1987). Again, funding issues does not seem to be the cause of the failure in the implementation of the SCP. Later on, despite the lack of success in proceeding with the SCP, Japanese investors purchased golf courses and land in several regions of the U.S. - San Francisco Bay Area, Napa Valley, San Diego, among others- aiming to build retirement communities (GROVES, 1990).

The main reason for the failure of SCP seems to be the lack of a strategy in presenting to the wide public the real value of what was being offered. There was a mismatch between the proponents' and the customers' thoughts, feelings and

17 "The phone calls flooded the Spanish Office of Tourism in Tokyo, which saw itself obliged to organize two meetings every week in order to explain how the country [Spain] is and answer the thorough questions of the new emigrants. These meetings were attended by 500 people and the waiting list has extended over a thousand" (Translated by me). 
actions with respect to the brand ${ }^{18}$. The core idea of SCP considered the provision of a pleasant experience to citizens advanced in age, but the image received by the Japanese retirees, the political opponents and part of the media was that SCP aimed solely to be a financial relief for the Japanese remaining in Japan. The opponents of SCP twisted the original style and tone in order to not fit the brand and the publicity was misunderstood as social marketing ${ }^{19}$. This can be illustrated by excerpts from the article "Anziani giapponesi prodotto d'esportazione" from Nuovo Paese, a monthly magazine of the Italian community in Australia:

“Il progetto 'Silver Columbia 1992' presenta aspetti molto interessanti, ma in qualche modo anche sconcertanti. É lodevole che si cerchino luoghi ameni affinchè gli anziani possano vivere in modo migliore la loro età. É lodevole che diventi um affare econômico: un business com risvolti di importanza internazionale. É encomiabile anche l'aspetto turistico-culturale dell'operazione, che può offrire conoscenze nuove, stimolanti interessi. Ma é sconcertante che l'operazione diventi uma vera e propria esportazione di anziani “ $(\mathrm{BOVO}, 1987)^{20}$

A later statement from the same article simply demonstrates the ignorance by its author about the differences in governmental structures between countries. There are social, political and historical trends to explain the national division of tasks and of range of responsibilities of each ministry. There were some changes since the 1980's, but, as an example, today in Japan, considerable portions of health, welfare and working conditions management are under the same ministry ${ }^{21}$. The second excerpt is as next:

18 A brand is the name, term, sign, symbol or design that identifies the maker or the seller of a product, which can be a tangible good, a service, an organization, a place, a person or an idea (KOTLER, ARMSTRONG; 2001; p. 301).

19 Social marketing can be defined as the use of marketing principles and techniques to influence a target audience to voluntarily accept a behavior for the benefit of the society as a whole (KOTLER, 2007; KOTLER, ROBERTO, LEE, 2004).

20 'The project 'Silver Columbia 1992' presents some very interesting but somewhat puzzling aspects. It is praiseworthy that we look for pleasant places so that the elderly can better live their age. It is praiseworthy as an economic deal: a business with implications of international importance. The touristcultural aspect of the operation is also praiseworthy, which can offer new knowledge, stimulating interests. But it is disconcerting that the operation is in fact an exportation of the elderly" (Translated by me)

21 "It is specified in Article 3, paragraph 1 of the Ministry of Health, Labor and Welfare Establishment Law: 'The Ministry of Health, Labor and Welfare aims to secure and improve the lives of the people in order to contribute to the economic development; social welfare; improvement and promotion of social security and public health; improvement of work conditions and other working conditions of workers; and, maintenance of occupations'”. (厚生労働省広報戦略会議, 2009, p.1, translated by me). 
"Il Giappone è un paese il cui governo dedica una mínima parte del proprio bilancio alla assistenza sociale e alla previdenza. (...) Il 'Silver Columbia 1992', quindi, si rivela un business ad alto livello sociale ed econômico. Lo dimostra il fatto che se ne è fatto promotore il ministero dell'Industria e del Commercio estero, quando invece era di competenza del ministero dell'Assistenza sociale o della Sanità" (BOVO, 1987)22

The project not only captured the media's attention, but also of a diverse group of academic researchers and communities of Japanese and their descendants - sometimes called nikkey - in foreign lands. Overall, the mentions and evaluations are brief, negative and highlight the failure in the negotiations between the Japanese representatives and local authorities or a supposed inconsiderate stance towards aspirations of people with advanced age. In Brazil, the Silver Columbia is briefly mentioned by Amorim (1991 apud AINDA, 1994), Rezende (2009) and a local newspaper (サンパウロ新聞，2012). The first is a master's dissertation in International Relations; the second, a book about the history of medicine; and, the third, a Japanese language newspaper from the city with the largest nikkey community in Brazil.

At the Universidad de Buenos Aires ${ }^{23}$ SCP was presented in a seminar as a bad example owing to the fact that policy makers allegedly did not consulted the Japanese retirees to define the details of the project, but this opposition fails in the sense that cannot be proved and it is anachronistic. Grunig's studies of models of public relations show that a modern view of democratic participation - with intense participation of the citizens together with politicians in discussing policy formulation - was an unusual way of enabling services in the 1980s (GRUNIG, 1989). Public relations related to products and services were mainly centered in one of the following strategies: propaganda; dissemination only of favorable information; or sophisticated attempts to manipulate the customer's intention. The idea of considering the importance of the "interdependence with publics that constrain the autonomy of organizations to pursue and meet their goals" is an ethical and socially responsible way of developing products and services that became part of the common sense only almost a decade after the SCP started to be discussed (GRUNIG, GRUNIG; 1991).

Yamada's article (2013) presents a group of elderly retirees who had a positive impression of the Silver Columbia Plan. These Japanese emigrated to Vancouver declared

22 "Japan is a country whose government devotes a small part of its budget to social assistance and social security. (...) The 'Silver Columbia 1992', therefore, proves to be a business of high social and economic level. This is demonstrated by the fact that the Ministry of International Trade and Industry promoted it, when it should have been responsibility of the Ministry of Social Welfare or Health" (Translated by me)

23 "De la aldea global a la aldea geriatrica" by Gonzalo Abramovich in the conference "Primer Encuentro Nacional Sobre Calidad de Vida en la Tercera Edad" held between 30 Sep. and 1 Oct. 1999 at the Universidad de Buenos Aires, Argentina. 
to have lived a great experience in the last 20,30 years since they left Japan (YAMADA, 2013). The possibility of being oneself and live in a way not confined to Japanese norms was the standard for the well-being of Yamada's informants. Takeuchi concludes with surprise that the idea of a happy couple enjoying together the last decades of their lives is not necessarily the reality of Japanese elderly retirement in Thailand (竹内, 2012). In many instances, the emigration is strategic and a way of finding the chosen life style later in life. Japan is a country where the social rules can be oppressive sometimes and for single healthy men in advanced ages, living abroad after retirement allows the fulfillment of a liberal personality.

The arguments against and for SCP presented in this paper are summarized in the Table 1. 
Table 1 - Arguments against and for SCP

\begin{tabular}{l} 
Arguments against SCP \\
\hline Risk of financial hardship in a foreign country \\
later in life \\
No benefits to host countries \\
Disregard towards sociocultural differences \\
between the Japanese and host societies \\
leading pensioners into unnecessary situations \\
of stress or conflict (GROVES, 1990) \\
\hline
\end{tabular}

Loose criteria to select destination countries

Long list of desired conditions, including natural, socioeconomic and political characteristics (EFE, 1986)

The service offered by SCP was not The LongStay Foundation, a for-profit commercially viable private institution, carried on with the project after being abandoned by the government (SCHREIBER, 2013; YAMADA, 2013)

Lack of interest from Japanese retirees to participate

The Spanish Office of Tourism in Tokyo was flooded by requests even before the SCP officially started (EFE, 1987)

Unfairness of using limited public funding in a project of high end retirement overseas

The Ministry of International Trade and
Industry was not the appropriate ministry to
organize the project, it should have been a
ministry related to welfare or healthcare

The funding would come primarily from the private sector (Japanese and international companies and retirees) (GROVES, 1990)

Tasks and range of responsibilities of government ministries are not the same in all the countries, an example is the Ministry of Health, Labour and Welfare (厚生労働省広報 戦略会議, 2009)

It is a State program to exile undesired citizens, the elderly, and remove them from their country of origin

It is a voluntary program which included the option for the retiree to return to Japan whenever (s)he desired so

It would never work out as it has been shut Some Japanese are living a good life in Canada down before it even began, without a chance of performing a test and Thailand after retirement (YAMADA, 2013; 竹内真澄, 2012)

Note: Arguments without reference were developed by me. 


\section{Conclusion}

The world is looking at the Japanese efforts and creativity to tackle social issues of today and tomorrow, such as population ageing and its implications. The study of SCP shows that Japan can look at herself, in the best spirit of 温故知新 ${ }^{24}$, learn lessons from its past and lead the global movement toward effective solutions. The lack of accessible and detailed documentation regarding the SCP made the study proposed by this paper quite limited. It is unusual to have good references regarding public policies that did not reached the step of full implementation, initiatives considered failed projects. However, even the evaluation of the plan and the intentions of SCP proponents by indirect sources allows drawing precious insights concerning the discussed themes.

The harsh criticism towards SCP from several sources reveals a preconception against ageing in a sense that it is associated with ideas of an undesired and overly vulnerable group in their own country without a place to stay or to go. The fallacy extends to an inevitable incapacity to choose lifestyle, to express aspirations, and a severe physical limitation to live an active life. For instance, data from the "Shakai Seikatsu Kihon Chousa" from the Ministry of Internal Affairs and Communications shows that elderly people have a significant participation in the daily average time of housework and childcare in families with working mothers. Tourism aiming to provide life experiences in advanced ages are a great way to promote cultural and economic relations between countries, as these retirees migration is not definitive and they receive visits from their families abroad. There is nothing wrong about that. Yet, it is not only unethical, but also meaningless to consider the portion of the population advanced in age only as a burden wherever they are, at their country of origin or at their country of destination. It is essential to promote the respect toward the elderly and change the way aging is understood today. As Sanderson and Scherbov $(2007 ; 2013)$ indicate, using the chronological age to evaluate individual behavior and public decisions concerning the pension and healthcare system is a limited point of view.

\section{日本語参考文献}

伊藤千恵 (2012)「懐かしい顔を囲んで思う」，『Costa アミーゴス コスタ・ デル・ソル 通信』第47号，p. 3 ，Costa Amigos 事務局。

厚生労働省広報戦略会議（2009）『厚生労働省広報基本指針』〈https://www. mh1w. go. jp/houdou_kouhou/d1/h240306.pdf>2018年 8 月 2 日アクセス
サンパウロ新聞
(2012)
『増加するのか、シルバー移住
（上）』〈https://goo.gl/
ZDxLRd>2018年 4 月 11 日アクセス

24 Onkochishin. Confucian principle of acquiring new knowledge from things past and tradition. 
竹内真澄 (2012) 「日本人退職者層の異文化居住-タイ在住ロングステイヤーの心理的 様相に関する一考察」，『多文化関係学』9，pp．3-19，多文化関係学会。

日本経済新聞（2008）『Y E N 漂流(5)-北畑次官の誤算』〈http://yenblog. seesaa. net/article/80773685. html>2018年 7 月 26 日アクセス

\section{References (English)}

ANDERSON, J. L.; RICHIE, D. The Japanese Film: Art and Industry. New York: Grove Press, 1960.

COULMAS, F. Population decline and ageing in Japan: the social consequences. London: Routledge, 2007.

GOODMAN, R.; HARPER, S. Japan in the new global demography: Comparative perspectives. In: The Asia-Pacific Journal, vol. 5, Issue 7, n. 0, pp. 1-9, 2007.

GROVES, M. Japan's Next Export May Be Its Elderly, U.S. Developer Suspects: Aging: Others, however, scoff at the suggestion that the Japanese are buying golf courses here as sites to build Asian retirement communities later. Los Angeles Times, Los Angeles, Mar. 5, 1990. Available at: <https://goo.gl/kHNBBn>. Accessed Dec. 15, 2016.

GRUNIG, J. E. Teaching public relations in the future. In: Public Relations Review, v. 15, Issue 1, pp. 12-21, 1989.

GRUNIG, J. E.; GRUNIG, L. S. Conceptual differences in public relations and marketing: the case of health-care organizations. In: Public Relations Review, v. 17, Issue 3, pp. 257-278, 1991.

JINUSHI, T.; KUROKI, Y.; MIYAO, R. Monetary policy in Japan since the late 1980s: Delayed policy actions and some explanations. In: POSEN, A. S.; MIKITANI, R. Japan's Financial Crisis and Its Parallels to US Experience. Washington: Institute for International Economics, 2000.

KOCH, M.; HERMER, C.; COULMAS, F. Trilingual Glossary of Demographic Terms: English-Japanese-German, Japanese-English-German, German-English-Japanese. Leiden: Koninklijke Brill, 2007.

KOTLER, P. Marketing in the public sector: a roadmap for improved performance. New Jersey: Pearson Education, 2007.

KOTLER, P.; ARMSTRONG, G. Principles of marketing. Upper Saddle River: Prentice Hall, 2001.

KOTLER, P.; ROBERTO, N.; LEE, N. Social marketing: Improving the quality of life. Thousand Oaks: Sage, 2004.

LADE, D. Japan considering relocating its elderly to foreign countries: the growing number of older people and limited housing has Japan thinking about "overseas Silver Towns". Sun Sentinel, Fort Lauderdale, Apr. 13, 1987. Available at: <http://articles.sun-sentinel.com/

1987-04-13/features/8701240033_1_japanese-older-people-silver-columbia-project $>$. Accessed Apr. 11, 2018. 
MARTIN, L. G. The graying of Japan. Washington: Population Reference Bureau, 1989.

MATSUTANI, A. Shrinking-population Economics - Lessons from Japan. Tokyo: International House of Japan, 2006.

MITSUBISHI CORPORATION. Japanese Business Glossary. Tokyo: Tōyō Keizai Shinposha, 1983.

SANDERSON, W. C.; SCHERBOV, S. A new perspective on population aging. In: Demographic Research, v. 16, pp. 27-58, 2007.

. The characteristics approach to the measurement of population aging. In: Population and Development Review, v. 39, n. 4, pp. 673-685, 2013.

SCHREIBER, M. Overseas voyages by retirees include more than a few shipwrecks. The Japan Times, Tokyo/Osaka, Feb. 24, 2013. Available at: <https://goo.gl/YpaEcE > . Accessed Dec.15, 2016.

SWINBANKS, D. Japan's sunset export industry. In: Nature, v. 322, p. 588, 1986.

TOYOTA, M.; BÖCKER, A. G. M.; GUILD, E. Pensioners on the Move: Social Security and Transborder Retirement Migration in Asia and Europe. In: Iias Newsletter / International Institute for Asian Studies, n. 40, pp. 30, 2006.

YAMADA, C. Achieving Dreams in One's Post-retirement "Second Life": A Study of Seniors' Migration from Japan to Canada. In: Senri Ethnological Studies - The Anthropology of Aging and Well-being: Searching for the Space and Time to Cultivate Life Together, v. 80 , p. 81-95, 2013.

YATES, R. E. Japan Finding spot for its Senior Citizens - Abroad. Chicago Tribune, Chicago, Oct. 15, 1986. Available at: <https://goo.gl/iylTPL >. Accessed Dec. 15, 2016.

\section{References (other languages)}

AINDA, M. L. Relação Brasil-Japão. In: Cadernos do IPRI, n. 12, pp. 26-50, 1994.

AMORIM, W. D. Contraste e contato: aspectos do relacionamento econômico entre Brasil e Japão. Brasília, Universidade de Brasília, Dissertação de Mestrado, Relações Internacionais, 1991.

BOVO, D. Anziani giapponesi prodotto d'esportazione. Nuovo Paese, Adelaide/Melbourne/ Sydney, Year 14, n. 5, p. 16, 1987. Available at: <http://filefaustralia.org/wp-content/ uploads/NuovoPaese_1974-2013/05_1987-Giugno.pdf $>$. Accessed Apr. 22, 2018.

CARONE, G. D. G. "Pour un thermalisme différent - considérations sur le cas de l'Italie". In: The Tourist Review, Vol. 44, n. 3, pp. 23-26, 1989.

EFE. España puede convertirse en un retiro de lujo para los jubilados japoneses. La Vanguardia, Barcelona, Aug. 14, 1986. Available at: <http://hemeroteca.lavanguardia.com/

preview/1986/08/14/pagina-18/32880888/pdf.html >. Accessed Jul. 28, 2018. 
. El Gobierno japonés promueve el retiro de pensionistas en la Costa del Sol. ABC Sevilla, Sevilla, Feb. 1, 1987. Available at: < http://hemeroteca.abcdesevilla.es/nav/

Navigate.exe/hemeroteca/sevilla/abc.sevilla/1987/02/01/033.html>. Acesse Apr. 22,. 2018.

GARCIA, R. La Costa del Sol Naciente. España es uno de los países onde Japón proyecta crear ciudades para sus jubilados. El País, Madri, Dec. 6, 1987. Available at: < https://elpais. com/diario/1987/12/06/espana/565743613_850215.html>. Accessed Apr. 22, 2018.

REZENDE, J. M. de. À Sombra do Plátano: Crônicas de História da Medicina. São Paulo: Editora Unifesp, 2009.

RIES, P. Ancianos en Japón. El País, Paris, Sep. 24, 1986. Available at: < https://elpais.com/ diario/1986/09/24/opinion/527896801_850215.html>. Acesse Apr. 22, 2018. 